Boise State University ScholarWorks

Political Science Faculty Publications and

Presentations

Department of Political Science

$1-26-2016$

\title{
Blog Consumption and International Relations
}

Michael A. Allen

Boise State University 
This is an author-produced, peer-reviewed version of this article. The final, definitive version of this document can be found online at Journal of Political Science Education, published by Routledge. Copyright restrictions may apply. doi: 10.1080/15512169.2015.1071264

\title{
Blog Consumption and International Relations ${ }^{1}$
}

\author{
Michael A. Allen \\ Department of Political Science \\ Boise State University
}

\begin{abstract}
Author Bio
Michael Allen is an assistant professor in the Department of Political Science at Boise State University. His research interests, in addition to teaching international relations, concern international conflict, relations between asymmetrically powerful actors in inter- and intra-state contexts (including war, civil war, and terrorism), and US foreign policy (including military basing and troop deployments). His work has also appeared in International Studies Quarterly, Conflict Management and Peace Science, and Foreign Policy Analysis.
\end{abstract}

\begin{abstract}
International relations professors have sought to incorporate current events into their curriculum through various mechanisms. A traditional way to incorporate the news into the classroom is to have students either subscribe and read a particular newspaper, or watch the nightly news, and hold them responsible for that information. However, with the growing body of profes sional political science blogs available to the general public, we now have access to immediate current event updates framed through the lens of political science. This manuscript tests to see if having students regularly read professional political science blogs increases student achievement on multiple choice exams when compared to students that were not following blogs in introductory to international relations courses. While controlling for other factors, the regression models demonstrate a $5 \%$ increase in performance on later exams by blog-consuming students over those who were not required to read blog posts. These results indicate that, in addition to other factors, there are pedagogical reasons to encourage (rather than prohibit) political science scholars from blogging.
\end{abstract}

Keywords: international relations, blogs, multiple choice, introductory, current events

\section{Introduction}

The number of political scientists (as well social scientists across every other discipline) that blog ${ }^{2}$ continues to increase. These blogs exist across several different axes of content and range from the personal to the professional, non-fiction to fiction, and individual to group content generation. How academic departments, universities, and professional organizations view blogs has not been consistent, but the prevalence of political science blogs does indicate some level of growing, though far from universal, acceptance. One recent example of note was an International Studies Association (ISA) Governing Council proposed policy that would forbid ISA journal editors (and members of the editing team) from maintaining or participating in blogging. Once revealed, this prompted furious discussion in various venues and ISA tabled the new policy for further review. ${ }^{3}$ Beyond our professional organizations, some universities have recently put limits on blogging by their professors as well (e.g. see Murdie 2014a). While there are compelling arguments in favor of blogging including professional development, developing a disciplinary and inter-

\footnotetext{
${ }^{1}$ I would like to thank the Boise State Teaching Scholars program's instructors and participants for both assisting, critiquing, and refining this work. Additionally, I would like to thank Andy Goodman, Julie VanDusky-Allen, Michael Flynn, and Michael Touchton for helping to improve both the research and the article. The author's institution's Institutional Review Board approved the research in this article.

2 Throughout the manuscript I use "blog" as a catch all to refer to periodically updated content posted publicly online that is not peer-reviewed. The term derives from the terms web log and weblog; I use the common term "blog" throughout the manuscript.

${ }^{3}$ For examples of this discussion, see Saideman (2014), Murdie (2014b), and Straumsheim (2014)
} 
This is an author-produced, peer-reviewed version of this article. The final, definitive version of this document can be found online at Journal of Political Science Education, published by Routledge. Copyright restrictions may apply. doi: 10.1080/15512169.2015.1071264

disciplinary discourse, and conveying recent research to the public, there are fewer arguments and research focusing on the pedagogical implications of academic blogging. This article offers insight into a method on how instructors can incorporate blog articles into the political science classroom and an evaluation of its effect on student performance in indirectly related tasks.

It is not uncommon for introductory courses to include some sort of media consumption within the classroom; a traditional route an instructor may employ would require students to subscribe to a newspaper (or tune into a particular daily news channel) for the semester and students would either answer questions about the content in daily or weekly quizzes and/or have questions on the exams related to the current events covered by those media outlets. Since the internet is now a prominent fixture in our daily consumption habits and our students are increasingly native to interacting and being on the internet (a recent poll shows that $71 \%$ of $18-29$ year olds self-report getting their news primarily from online sources (Pew Research 2013)), adding required reading by including regularly updated political science and international relations blogs may be an appropriate substitute for having political science students digest current events via a newspaper subscription. The added benefit of focusing on academic blogs is that the authors will likely discuss current events in terms and concepts that the students are becoming familiar with throughout the semester.

In this article, I analyze data from a yearlong study on the effect of assigning blog content in the classroom. While several studies have looked at how writing blogs can enable students to understand and express ideas, few studies look at the impact of reading professionally written blogs on student achievement. Comparing two semesters of "Introduction to International Relations" taught at a large regional college, I find that incorporating blog consumption into a course syllabus generally improves student performance by 4-5 percentage points on major exams. This article proceeds as follow: the next section engages the literature and theoretical arguments as they relate to blogging. The subsequent section leads to the methodological process in which I analyze whether consuming political science blog posts affects student performance in introduction to international relations courses. The subsequent section presents and analyzes the data. The final section discusses the implications of this research and its practical extensions.

\section{Bringing Political Science Blog Posts into the Classroom}

It is an understatement to say that blogs have not escaped the attention of academics; they have proliferated through all levels of academia - from undergraduate majors, graduate students, junior faculty, and to full professors-as a communication and writing medium. Most commonly, academics use blogging as an outlet for writing. Blogging as such an outlet can range from a form of public diary writing to professional research. Blogging as an outlet for research has a few different practical uses and benefits for academics. Blogging can supplement any part of the research process including formulating and soliciting ideas, testing out arguments with an audience, engaging with an audience informed on this and other topics that you are writing on, discussing preliminary results, posting conference papers, publicizing publications, distilling academic research for a more general audience, and several other functions with primary and secondary benefits. Scholars across disciplines engage audiences through this medium as a way to encourage and distribute their research.

Beyond aiding the research process, blogs also intersect with the classroom. The vast majority of contemporary research looks at blogging as a forum students can participate in by maintaining their own blogs and further their own academic comprehension. Kim (2008), while reviewing the contemporary scholarship on blogging, finds it incompletely studied as an alternative to other forms of computer-mediated communication applications. That is, given other software alternatives, there is not enough research that show blogs to be unique or advantageous over other online interaction such as discussion boards. There is some evidence that students' blogging may experience higher levels of interactivity with other students and instructors, but students participating in group blogs are less likely to continue to blog in the future when compared to students working on solo-authored blog posts (Divitini, Hauga- lokken and Morken 2005; Kim 2008; Lin, Liu, Kakusho, Yueh, Murakami and Minoh 2006). Kang, Bonk and Kim (2011) use blogging as a central tool in facilitating discussion for two graduate seminars in Korea. The authors find that the decentralized interactions between students and instructors led to a rich dialogue between the participants and enabled the students to gain experience in constructing and refining ideas. 
This is an author-produced, peer-reviewed version of this article. The final, definitive version of this document can be found online at Journal of Political Science Education, published by Routledge. Copyright restrictions may apply. doi: 10.1080/15512169.2015.1071264

Sim and Hew (2010) review a large swath of literature on using blogs in the classroom. In their review, they find six different ways in which instructors typically utilize blogs in the classroom: Blogs as learning journals, blogs as personal diaries, blogs as outlets for emotional expression, blogs as interpersonal dialogue, blogs as writing and assessment tools, and blogs as a task management tool. The authors find that the current empirical evidence on the research of the effectiveness of blogs in the classroom is lacking as the present empirical research relies on selfreported data. However, with the understanding that self-reported data on performance-related outcomes are unreliable, the researchers do suggest that there is a general positive trend between incorporating blogs into the classroom and student learning.

While the present research typically focuses on a different question than the present manuscript, there are a few hints that reading current events might be beneficial to student learning. While some political science courses introduce or require students to keep up with current events through either physical newspapers, online newspapers, or a news channel, much of the research on the effectiveness of current events in teaching comes from other arenas (such as secondary school classrooms) or disciplines. For example, there is evidence that reading newspapers in a foreign language can enhance student mastery over that language (Lee 1999) and scholars have long argued that introducing newspapers into the classroom encourages critical thinking (Harvey and Denton 1938). Additionally, students in secondary schools were more likely to be interested in a subject matter if it tied to current events in the news articles they read (DeRoche 1981). Instructors also find it useful in the physical sciences in relating contemporary science debates and discoveries to classroom materials (Jarman and McClun 2001; Shibley Jr. 2003).

These cases are not exactly analogous to political science blogs, but they do have a few important connections. First, like the secondary language research, political science has its own jargon and style of communication that students are unlikely to be familiar with. Giving students the opportunity to immerse themselves into the language of political science can further enable their comprehension of abstract or difficult concepts; if this analogy holds, it also should enable students to express ideas through a political science framework. Additionally, connecting foundational concepts of political science to contemporary events may enhance students' interest in the material of the class.

Current events offer a unique nexus for political science pedagogy as they can illustrate the applied foundation to our theoretical models. While politics and political science are not synonymous, ongoing real world events can serve to provide context for students at every level of understanding. A student immersed in contemporary politics may find it easier to understand the underlying processes of political systems. However, it is not guaranteed that our median student will be well versed in current politics as the average first year college student's knowledge of political processes is likely to be shallow (Heron and McManus 2003). Requiring students to be accountable for current events may give them some additional background in contemporary politics that is lacking among their peers.

Instead of assuming our students are well versed in contemporary world news, some instructors seek to increase current event literacy by making current events part of the course and coursework. A traditional method to introduce current events into the classroom would be to require students to have a newspaper subscription and the students become responsible for the daily news. Instructors can reinforce daily consumption of newspapers by making it part of other course work (such as writing assignments) or having regular (or random) quizzes on the material they are reading. This method of introducing current events into the political science classroom is noteworthy as it does elevate the median student's comprehension of politics; however, this method has two arguable flaws. First, newspapers are not written for political scientists, people versed in political science literature, or undergraduates generally. Newspapers offer a journalistic view of the world. While this is valuable, it requires a different form of literacy comprehension than what students normally read in a political science classroom. A reliance on our journalistic sources teaches our students another skill set, but does not necessarily reinforce the primary concepts and skills we offer in our classes.

Second, recent generations of undergraduate students are increasingly less familiar with newspapers. Polls consistently find that fewer people get their news primarily from newspapers but, instead, find it online from sources such as news websites, social media, and blogs (Pew Research 2013). As the undergraduate population becomes less familiar with newspapers, the political science course that uses newspapers will demand additional work of students to familiarize them- selves with an unfamiliar medium. This unfamiliarity presents a barrier to comprehension and mastery as it is another step students must endure to access the material we want them to learn. While this may 
This is an author-produced, peer-reviewed version of this article. The final, definitive version of this document can be found online at Journal of Political Science Education, published by Routledge. Copyright restrictions may apply. doi: 10.1080/15512169.2015.1071264

seem like a trivial demand upon students, having students engage material that allows for the greatest amount of transference of skills from what they already do daily allows them to grasp the content and meaning of the material more quickly.

Since current students are getting the vast majority of their information and news from the Internet, each new generation of undergraduates necessarily will have fewer individuals who knew life without the world wide web. Given this inherent familiarity, using online resources to introduce current events offer a minimal-cost mechanism that students are already familiar with. Additionally, instructors have a variety of types of online sources they can use to engage their students. In this study, I specifically focus on blogs maintained by political scientists who write about contemporary political science literature in reference to ongoing events. Thus, I opted to have my students read current events research written through a political science perspective. Such blogs offer scholarship that more similarly matches the other reading they are consuming during the course (such as textbooks) and is likely to highlight material that may be most relevant to the concepts the students are actively engaging.

The goal of this project is to determine whether academic blogs on international relations and political science can facilitate student's mastery over basic and applied concepts in introduction to international relations. Testing students that read blogs on their mastery over current events in comparison to those who did not read blogs would not be a compelling test; those that I require to read have an extrinsic incentive to understand them and it would be a biased test. Instead, the real test for this study is whether those who read blogs are able to perform better on the other material covered within the course; this research seeks to ascertain if blog consumption increases academic achievement in an introductory international relations course. To this end, I expect the following relationship:

Hypothesis 1. Students who read political science blogs will perform better on introduction to international relations exams than students who do not read political science blogs.

\section{Methodology}

\section{Course Description}

To study the influence of blog reading in the classroom, I assessed two of my 300-level introduction to international relations courses in the 2013-2014 academic year. To enroll in the course, students must take a lower-level introduction to political science course or receive instructor permission. Given this requirement, the vast majority of students are political science majors or minors with a few upper level students from other social science disciplines. The maximum class size is thirty- five students and the course is mostly lecture-based.

The students use one textbook (World Politics: Interests, Interactions, Institutions (Frieden, Lake, and Schultz 2012)) in addition to two popular press books. ${ }^{4} 90 \%$ of student's grades come from the following: $20 \%$ for a fivepage reaction paper to either popular press book, $25 \%$ for a final paper that tests an international relations hypothesis, and $45 \%$ for three non-cumulative exams approximately every five weeks. The exams consist of roughly 50 multiple choice questions which students answer in a single course period (75 minutes). The final $10 \%$ of their grade comes from quizzes and these varied across each semester as described in the following section.

Due to differing holiday schedules between the fall and spring semesters, coverage on topics is not identical and the exams are not complete copies of each other, but they do have significant overlap. The first exam shares 48 questions between the courses, the second exam shares 48 questions, and the final exam shares 41 questions.

\footnotetext{
${ }^{4}$ I regularly rotate the other two books in my course. As such, the fall semester read Nagl (2009) and Bates (2001) while the spring semester read Drezner (2011) and Bates (2001). The students in both courses read the Drezner or Nagl prior to the first exam. This difference in the courses did not lead a significantly different performance on the first exam were such an effect was most likely to be evident. Excluding questions related to either books on the first exam does not affect the inferences I draw from the data.
} 
This is an author-produced, peer-reviewed version of this article. The final, definitive version of this document can be found online at Journal of Political Science Education, published by Routledge. Copyright restrictions may apply. doi: 10.1080/15512169.2015.1071264

\section{Experimental Approach}

In the fall of 2013, I did not require my students in my 300-level course to follow and read blogs. The part of the course that I replaced in the spring semester is a series of five quizzes on geography. I gave the fall semester students a list of countries in each of five regions (the Americas, Asia, the Middle East, Africa, and Europe) and they name ten of those countries that I randomly assign on a blank map. I did not conduct this series of quizzes in my spring 2014 class.

In the spring of 2014, instead of offering map quizzes, I required weekly quizzes (the second class (a Wednesday) of every week) in which students were responsible for any material covered on the blogs from the previous four business days (Thursday, Friday, Monday, and Tuesday). I as- signed students to keep up with daily postings from the political science oriented blog The Monkey Cage and the international relations focused blog The Duck of Minerva. ${ }^{5}$ These two blogs are the prominent group blogs of political science and international relations research. The Monkey Cage is a general political science blog that draws from all of the subfields of political science while The Duck of Minerva contains posts by a group of international relations scholars. Both blogs contain a mixture of posts that are both relevant to the introductory course as well as posts that are less relevant to the course (e.g. posts that are personal in nature, deal with the business of political science, or discuss another subfield). As such, I instructed students to read posts that relate to issues of comparative politics and international relations. Given that this was an introductory level course, I provided some initial guidance as what would likely show up on an exam (such as a post dealing with government structures in other countries or foreign policy decision making processes) and what I would not quiz them on (for example, a post on campaign finance reform within the United States). ${ }^{6}$

Every Wednesday, students, had a five-question exam, with a mixture of question types. Typically, an exam would include True/False (e.g. True or False: Women, in the US military, are currently excluded from active combat in Afghanistan), multiple choice (e.g. What country approved a global cap on immigration over the past weekend? A. The United States, B. South Korea, C. Denmark, D. Switzerland, E. Norway), and short answer questions (e.g. What is the strongest predictor of Russian dissatisfaction with Putin?); the questions covered factual, theoretical, methodological, and applied topics. The quizzes did not occur during weeks that contained an exam or a paper due date. There were nine blog quizzes during the spring semester. The cumulative value of the quiz grades was worth $10 \%$ of the student's final grade.

As noted before, the exams were similar for both semesters. I did not include map quiz material nor blog material directly on the exam, but focused on material covered within the assigned reading and lecture material. The goal of the study is to see if the blog readings reinforced other concepts from the class and including current event questions on the exam would not actually measure this.

\section{Data}

The majority of the data I use to tease out the effects of blog quizzes derives from in-class performance on assignments. Given the structure of the class, there is opportunity to see how student performance on various components of the course as it relates to their exam performance. The unit of analysis is the student. The primary dependent variable is

\footnotetext{
${ }^{5}$ I am not a contributor to either blog.

${ }^{6}$ I made the exam wider than traditional international relations for both pedagogical and practical reasons. Gener-ally, having a wider knowledge of how non-American countries operate would benefit the students' comprehension of global politics. Additionally, I initially had concern that there may not be enough International Relations-centric posts across both blogs to fuel a diversity of questions on a weekly basis and I did not want to overload the students on too many different blogs. The focus on comparative and international relations topics provided sufficient coverage most weeks, though there were a few weeks were the number of applicable articles seemed daunting to students.
} 
This is an author-produced, peer-reviewed version of this article. The final, definitive version of this document can be found online at Journal of Political Science Education, published by Routledge. Copyright restrictions may apply. doi: 10.1080/15512169.2015.1071264

the exam grade by each student as a percentage of total possible correct answers. In my analyses, I examine the effects of the covariates on exams 1,2 , and $3 .^{7}$ Table 1 contains the descriptive statistics of both dependent and independent variables.

The variable Spring 2014 is a dichotomous variable for whether a student was in the spring or

Table 1: Summary Statistics for Dependent and Independent Variables

\begin{tabular}{|c|c|c|c|c|c|}
\hline Variable & Observations & Mean & Std. Dev. & Min & Max \\
\hline Spring 2014 & 64 & .547 & .502 & 0 & 1 \\
\hline Gender & 64 & .375 & .488 & 0 & 1 \\
\hline Standing & 64 & 2.98 & .882 & 1 & 5 \\
\hline Exam 1 & 64 & .671 & .140 & .294 & .923 \\
\hline Exam 2 & 62 & .696 & .1298 & .294 & .959 \\
\hline Exam 3 & 60 & .605 & .139 & .26 & .878 \\
\hline Quiz Before Exam 1 & 64 & .839 & .186 & 0 & 1 \\
\hline Quiz Before Exam 2 & 64 & .717 & .238 & 0 & 1 \\
\hline Quiz Before Exam 3 & 64 & .807 & .2741 & 0 & 1 \\
\hline Final Paper & 62 & .8575 & .169 & 0 & 1 \\
\hline
\end{tabular}

fall class; a value of one indicates a spring semester student. This is my primary variable of interest as I expect the spring semester students to do better on the three exams than the fall students. The spring students read the political science blog posts and took the blog quizzes instead of map quizzes.

Additionally, for each exam I predict (three total), I use a variable to indicate their average, non-cumulative score on quizzes prior to the exam as a percentage of points possible (Quiz before Exam \#). I use the non-cumulative score (instead of the total quiz average) to ensure a proper temporal causal order between quizzes and exams-using future quiz scores to predict past exams will likely lead to improper inferences. For the fall students, this is their map quiz score; the variable tracks the blog quiz score for the spring students. For the fall semester, there were two map quizzes before the first exam, two before the second exam, and one before the final exam. In the spring semester, there were three blog quizzes before the first exam, four before the second exam, and two before the final exam.

The quiz score variables captures two interesting effects. First, these variables are non-endogenous in that the exam scores should not affect the previous quiz scores. This creates a causally direct link where we expect those that do well on quizzes should also do well on the exams. However, the exams do not cover material directly from either the blog or map quizzes. As such, the quiz variable acts as a partial control for high achievers within the course. This isolates the treatment effect more (spring semester) as the independent variable of interest looks purely at exposure. If the spring semester students are naturally higher achievers than the fall semester students for variables that I cannot measure, it should show up in the quiz scores and the quiz scores will predict the exam scores.

In predicting student performance on the second (Exam 2) and third exam (Exam 3), I use the students' previous exam performances as I expect students to maintain some level of consistency. The exams are not cumulative, so while students may be learning how to take multiple choice exams, they are not doing better because they are seeing questions on identical content. Generally, I expect the processes to be Markovian in that the performance on exam 1 should not affect exam 3 if we include exam 2, but this is not a necessary assumption for the models to work.

\footnotetext{
${ }^{7}$ As evidenced in Table 1, my exams tend to be difficult for the average student. I intentionally construct scalable multiple choice exams with questions of varying difficulty to allow me to see what different levels of comprehension students obtain from class material and to encourage a normal distribution of grades. After knowing the grade distribution, I adjust the grades based on class performance; the variables in this study do not reflect that adjustment but instead reflect the actual scores.
} 
This is an author-produced, peer-reviewed version of this article. The final, definitive version of this document can be found online at Journal of Political Science Education, published by Routledge. Copyright restrictions may apply. doi: 10.1080/15512169.2015.1071264

Finally, for the third exam, I use the students' score on their final paper (Final Paper) to assess if a writing component of the course correlates with higher achievement on the exam and, like quiz scores, acts as a partial control for exogenously high achievement.

In addition to the in class performance metrics, I use two directory variables for the students: Standing and Gender. Standing ranges from 1-5, where one through four indicates a first through fourth year student (by credit hours). Values of five indicate post-baccalaureate students. I expect students who are higher standing to perform better on exams than students with fewer completed credit hours. Gender is a binary variable where zero indicates male and one indicates female. I do not have an expectation that women or men would do significantly better than the other in international relations exams. However, there is a difference in the gender balance within the class room (about 2:1 in favor of men). Additionally, some research suggests a gender bias against women in multiple choice exams (Arthur and Everaert 2012; Bridgeman and Lewis 1994), but the research remains conflicted on this issue as other studies suggest that there is not a statistically significant difference in performance (Bacon 2003; Ghorpade and Lackritz 1998).

\section{Results and Analysis}

Table 2: Student Performance on Introduction to IR Exams

\begin{tabular}{|c|c|c|c|c|c|}
\hline & $\begin{array}{l}\text { (1) } \\
\text { Exam } 1\end{array}$ & $\begin{array}{l}(2) \\
\text { Exam } 2\end{array}$ & $\begin{array}{l}\text { (3) } \\
\text { Exam } 2\end{array}$ & $\begin{array}{l}\text { (4) } \\
\text { Exam } 3\end{array}$ & $\begin{array}{l}\text { (5) } \\
\text { Exam } 3\end{array}$ \\
\hline Spring 2014 & $\begin{array}{c}-0.0234 \\
(0.0352)\end{array}$ & $\begin{array}{c}0.0537 * * \\
(0.0281)\end{array}$ & $\begin{array}{c}0.0507^{* *} \\
(0.0214)\end{array}$ & $\begin{array}{c}0.0577 * * \\
(0.0219)\end{array}$ & $\begin{array}{c}0.0558^{* *} \\
(0.0219)\end{array}$ \\
\hline Gender & $\begin{array}{c}-0.0552 * * \\
(0.0290)\end{array}$ & $\begin{array}{c}-0.0780 * * * \\
(0.0264)\end{array}$ & $\begin{array}{l}-0.0250 \\
(0.0233)\end{array}$ & $\begin{array}{l}-0.0158 \\
(0.0200)\end{array}$ & $\begin{array}{l}-0.0186 \\
(0.0207)\end{array}$ \\
\hline Standing & $\begin{array}{r}-0.01000 \\
(0.0263)\end{array}$ & $\begin{array}{l}-0.0307 \\
(0.0218)\end{array}$ & $\begin{array}{c}-0.0149 \\
(0.0141)\end{array}$ & $\begin{array}{c}0.0196 \\
(0.0166)\end{array}$ & $\begin{array}{c}0.0181 \\
(0.0170)\end{array}$ \\
\hline Quiz Before Exam 1 & $\begin{array}{c}0.356^{* * *} \\
(0.0857)\end{array}$ & $\begin{array}{c}0.217^{* *} \\
(0.111)\end{array}$ & $\begin{array}{c}0.0591 \\
(0.0728)\end{array}$ & $\begin{array}{c}-0.0887 \\
(0.0739)\end{array}$ & $\begin{array}{l}-0.0857 \\
(0.0739)\end{array}$ \\
\hline Quiz Before Exam 2 & & $\begin{array}{c}0.294^{* * *} \\
(0.0840)\end{array}$ & $\begin{array}{l}0.123 * * \\
(0.0527)\end{array}$ & $\begin{array}{c}0.223^{* * *} \\
(0.0525)\end{array}$ & $\begin{array}{c}0.207^{* * *} \\
(0.0527)\end{array}$ \\
\hline Quiz Before Exam 3 & & & & $\begin{array}{c}0.0244 \\
(0.0386)\end{array}$ & $\begin{array}{c}0.0312 \\
(0.0385)\end{array}$ \\
\hline Exam 1 & & & $\begin{array}{c}0.655^{* * *} \\
(0.104)\end{array}$ & $\begin{array}{c}0.221 \\
(0.139)\end{array}$ & $\begin{array}{c}0.233^{*} \\
(0.143)\end{array}$ \\
\hline Exam 2 & & & & $\begin{array}{c}0.550^{* * *} \\
(0.134)\end{array}$ & $\begin{array}{c}0.531^{* * *} \\
(0.140)\end{array}$ \\
\hline Final Paper & & & & & $\begin{array}{c}0.0734 \\
(0.0671)\end{array}$ \\
\hline Constant & $\begin{array}{c}0.435 * * * \\
(0.0836)\end{array}$ & $\begin{array}{c}0.387 * * * \\
(0.0859)\end{array}$ & $\begin{array}{c}0.139 * \\
(0.0705)\end{array}$ & $\begin{array}{c}-0.124 \\
(0.0753)\end{array}$ & $\begin{array}{l}-0.173^{* *} \\
(0.0834)\end{array}$ \\
\hline $\begin{array}{l}R^{2} \\
\text { Observations }\end{array}$ & $64^{0.229}$ & 0.353 & $62^{0.693}$ & $60^{0.772}$ & $60^{0.776}$ \\
\hline
\end{tabular}

Robust standard errors in parentheses

One-tailed significance tests: ${ }^{*} \mathrm{p}<0.1,{ }^{* *} \mathrm{p}<0.05,{ }^{* * *} \mathrm{p}<0.01$

Table 2 presents the results from five different ordinary least squares regressions predicting the score of students on various exams throughout the semester. Model 1 offers the results for the first exam with only showing a positive relationship between the quiz scores and exam score and a higher score for men over women on the first exam. The primary variable of interest, spring 2014, does not have a significant relationship with the student's performance. 
This is an author-produced, peer-reviewed version of this article. The final, definitive version of this document can be found online at Journal of Political Science Education, published by Routledge. Copyright restrictions may apply. doi: 10.1080/15512169.2015.1071264

However, by this point in the semester, student had only read three weeks' worth of blog posts and had three quizzes on the material they covered. If the hypothesis I propose is accurate, there are two viable explanations for this null finding. First, it is possible that the treatment duration was not long enough and students did not have enough time to incorporate fully this aspect of the course into their learning. Second, the blogs may not have covered the topics covered in the first exam.

Model 2 is more promising for the main hypothesis as it suggests a $5.27 \%$ increase in performance for the spring students on the second exam. Of note, the quizzes prior to exam 1 and exam 2 are positive and significant while gender remains negative. However, model 3 complicates this picture a bit more by incorporating the student's performance on the first exam. Not surprisingly, how well students did on the first exam is a strong predictor for how well they did on exam 2. This also causes a large jump in the $R^{2}$ as exam 1 is a very strong predictor of exam 2 . Once we incorporate this information from exam 1, two variables change in their significance. First, the quizzes from before the first exam no longer significantly predict the performance on exam 2. This information appears absorbed by the exam variable itself (as we expect from a Markovian process). This is an intuitive result as these two variables correlate (as per model 1) and we expect the information provided by exam 1 to dwarf that provided by the first set of quizzes. A second, surprising result surfaces as well. Both model 1 and model 2 suggests that women, on average, perform 5.5$7.7 \%$ worse on these exams than men. However, once we incorporate the information from exam 1, this gender bias dissipates. That is, gender does not seem to compound the performance of students in future exams, but is isolated to an introductory effect absorbed by the students' performance on the first exam. After the first exam, gender does not predict student performance. Finally, the magnitude of the semester variable shifts downwards slightly, but still hovers around a five-percent bump for the blog-consuming students.

The fourth and fifth models examine whether these relationships persist through exam three. ${ }^{8}$

The semester variable improves mildly in the third exam and offers a 5.5-6\% increase in student performance. This result is consistent with exam 2, but is also likely diminished by the presence of exam 2 in the estimation. Since spring produces a $5 \%$ bump in exam 2, and exam 2 is a significant and strong predictor for exam 3 , the dichotomous semester variable may have an additional, indirect effect of up to $2.5 \%$ (i.e. the total influence of the variable on exam 2 multiplied by the total influence of exam 2 on exam 3). Indeed, removing the exam covariates from the equation boosts the effect of Spring 2014 to $8.69 \% .^{9}$ Gender remains insignificant. Exam 1 appears to have a barely significant effect on exam 3, though the magnitude is large, while exam 2 provides the strongest predictor for exam 3 in magnitude and substance. Somewhat perplexing, the quizzes before exam three seem to offer no predictive power for the third exam. There are a few reasons for this result. Perhaps the most likely explanation is, for the spring class, the quizzes prior to exam 2 represent the plurality of the quizzes and may be the best representation of student achievement outside of the test. The final paper does not significantly correlate with students' final exam grades in model five, which reinforces the research that suggests constructed response ${ }^{10}$ and multiple choice questions require different skill-sets from students and do not necessarily correlate, especially when the tasks do not mirror each other's content uniformly (Rodriguez 2003; Traub and Fisher 1977).

\footnotetext{
${ }^{8}$ I have examined the reported models using only the questions each course shared. When estimating models for shared questions only, the primary independent variable of interest remains significant and positive with some fluctuation in the magnitude of the coefficient. Three shared questions included language changes: A question on exam 1 had two right answers (students were given full credit in the fall semester for either answer but not the spring students), a second question on exam one had an answer with a slight language change (from the adjective domestic to substate), and a correct answer for a question on exam 2 removed references to the United Nations as we did not cover the organization in detail in the spring semester. When eliminating both non-shared and changed questions, five questions from the second exam, the estimates for Spring semester in model two does lose significance; but retains its significance when incorporating the first exam score in model 3.

${ }^{9}$ Regression not reported in this article.

${ }^{10}$ Paper writing is not directly equivalent to answering constructed response questions in exams, but the research is relevant here as it does suggest student writing does not correlate well with multiple choice exams.
} 
This is an author-produced, peer-reviewed version of this article. The final, definitive version of this document can be found online at Journal of Political Science Education, published by Routledge. Copyright restrictions may apply. doi: 10.1080/15512169.2015.1071264

\section{Blogs and Specific Question}

Another potential use of this data is to see what kinds of questions students did better on in the spring than in the fall. Using a series of logit models while controlling for gender and student performance, ${ }^{11}$ I evaluated all the shared questions to see which kinds of questions the spring group was statistically more likely to get right. Due to space consideration of the nearly 130 regression models, I do not report the models, but summarize the distinctions.

In exam 1, there are six questions that the spring semester was more likely to get correct than the fall semester with all else constant. These included questions about population growth and state formation, game theory (including utility theory and strategic interactions), and levels of analysis in explaining war. In exam 2, ten shared questions favored the spring semester students. These topics included terrorism, civil war, guns versus butter theory as it relates to foreign policy and alliance formation, and economies of scale in production. For exam 3, four questions provided the spring semester an advantage. This included question about different monetary systems, global energy consumption, and sanctions and the sanctions paradox.

While not all of this variance can be strictly explained by student consumption of ongoing events, a large portion of it can be. Most significantly, after the first exam, Russia invaded Ukraine and occupied the Crimean peninsula. This event spawned numerous articles that ran the gamut of international relations topics and how it explained the Ukrainian-Russian conflict, but it certainly was not the only current event that helped underscored the information covered in the course. The first third of the class discusses theoretical approaches to international relations as well as the substantive topics of war, civil war, terrorism, and alliances. The Ukrainian-Russian motivated bloggers to discuss whether realpolitik was alive and well or if other theoretical processes explain the conflict (Hayes 2014, Travlos 2014). The blog post "Cutting arms and tying hand" and a second one on crisis escalation underscored what students learned about and were tested on for the bar- gaining model of war, commitment problems, and information asymmetries (Radnitz 2014, Ward \& Musgrave 2014). Terrorism and civil war received several articles on topics including the Muslim Brotherhood in The Monkey Cage (Nugent 2014, Lacroix 2014), protests and violence (Onuch and Sasse 2014; Wolczuk and Wolczuk 2014), terrorism (Thomas 2014a), the effect of democratic institutions on the prospects for civil war (Steele 2014), internal security dilemmas (Benstead, Kjaerum, Lust, and Wichmann 2014), and the role of international organizations in resolving disputes (Voeten 2014b). The Duck of Minerva article on estimating drone casualties reinforced concepts of measuring and reliability that we discussed in covering the scientific method in relation to social science (Carpenter 2014).

The second third of the course focuses on international political economy and incorporates economic processes. Blog posts on the relationship between trade, international commerce, and conflict (Gartzke and Lupu 2014; Mueller 2014) and the relationship between domestic politics, foreign aid, and foreign policy (Goldsmith, Horiuchi, and Wood 2014; Izama and Dionne 2014) combined with previous posts to offer further avenues of international relations scholarship. The final third of the class focuses on topics such as human rights, the environment, weapons of mass destruction, and changes in global power (e.g. the rise of the People's Republic of China and what we have learned from the British demise leading up to World War I). The blogs furthered students understanding of these topics when authors wrote about the sanctions paradox (Arena 2003; Drezner 2003; Marten 2014), shifts in power in traditional (Thomas 2014b, Stacey 2014) and non-traditional venues such as cyber- security (Farrell 2014a, Farrell 2014b), and the role of ethnic fractionalization during genocide (Voeten 2014a).

The breadth of topics covered by the blogs in the period from the end of January through the beginning of May in 2014 is broad and is covered by a range of academics from promising graduate students, junior scholars, to prominent experts. This list is a subset of what the students read; having the secondary reinforcement, in addition to their other readings and lecture, provides another opportunity for students to grapple with difficult international relations concepts.

While the students in the spring did better on some questions, they also did worse on other questions. Since I cannot control either the content of the two blogs or current events, it is likely that there will be intra-semester variance around what issues are prominent in both the public's and scholars' minds if future courses decide to adopt blogs.

\footnotetext{
${ }^{11}$ For exam 1 questions, I controlled for quiz 1; for exam 2, I controlled for exam 1; and for exam 3, I controlled for exam 2.
} 
This is an author-produced, peer-reviewed version of this article. The final, definitive version of this document can be found online at Journal of Political Science Education, published by Routledge. Copyright restrictions may apply. doi: 10.1080/15512169.2015.1071264

\section{Post-Class Survey}

Table 3: Student Performance on Introduction to IR Exams

\begin{tabular}{lccc}
\hline \multicolumn{1}{c}{ Question } & Obs. & Mean & Std. Dev. \\
\hline \hline $\begin{array}{l}\text { The blog quizzes were useful in giving real world } \\
\text { examples for what we talked about in class. }\end{array}$ & 29 & 4.75 & .43 \\
$\begin{array}{l}\text { The blog quizzes were an enjoyable part of class. } \\
\text { The blogs gave me an idea as to what political sci- }\end{array}$ & 29 & 3.55 & .72 \\
entists were actively researching. & 29 & 4.52 & .56 \\
$\begin{array}{l}\text { Studying for blogs quizzes was too time consum- } \\
\text { ing. }\end{array}$ & 28 & 3.04 & .96 \\
$\begin{array}{l}\text { I discussed the blogs with other students outside of } \\
\text { the class. }\end{array}$ & 29 & 3.48 & \\
\end{tabular}

A third, aggregate source of data worth briefly reviewing is the survey that accompanied my end of semester evaluations. In addition to normal questions evaluating the course and the instructor, I asked students for feedback on the blog quizzes with five statements that they rated using a five- point scale that included: strongly disagree, disagree, neutral, agree, and strongly agree. Table 3 summarizes those results.

Generally speaking, the students overwhelmingly agreed that the blog assignment both gave them concrete examples to work with as well as providing them an idea of what kind of research political scientists conducted. In terms of the first question, no student rated it below a four (Agree) and the third statement only had one student scoring it below a four. In regards to enjoyability (a risky question to ask any student) the modal response was neutral. One student found it to be unenjoyable while the remaining 14 agreed or strongly agreed with the enjoyability. Sixteen of twenty-eight students were neutral or disagreed that the blog quizzes were time consuming, while the remaining 12 responded with a four (Agree) to the question. Finally, 15 of 29 respondents said that they discussed the blog material with other students outside of classroom. I asked this final questions to see if the blog quizzes encouraged the students to discuss and reinforce any of the material outside of the classroom; for half of the class, the blog posts entered into their interpersonal discussions.

These self-reported results suggest that the blog quizzes serve useful pedagogical functions outside of the classroom. Students feel more informed both about current events and political science research. The former is a typical goal of political science courses, but we often ignore the latter in designing our courses. Using these two blogs seems to give students both a sense of politics as well as political science.

\section{Conclusions}

There are several reasons why international relations (and political science generally) scholars ought to blog. The activity can make our research more accessible and usable to the public, it can aid in all steps in the research and writing process, and it allows scholars to reach out and speak to each other in ways peer-reviewed papers and conference presentations do not enable. Additionally, blogs cover events in a more real time manner than other scholarly outlets - this temporal nature can capture student interest while events are still fresh rather than months or years later. This manuscript offers an evidence-based result to add to the portfolio of reasons above: it has benefits in the classroom. Not only does it make our research readily presentable to our own students, but our online posts can be consumed by other students inside and outside political science and can increase student exposure as to how our theories and research apply to the real world. It also offers a concreteness that enables academic achievement as students get a better grasp of how our theories explain real-time events and not just the past few major wars they read about in their textbooks.

A few challenges to my results exist; first, the students in the spring semester course that followed current events also were exposed to an ongoing-crisis that was interesting and relevant to international relations students: Russia invaded and occupied the Crimea region of Ukraine. This event galvanized international relations blogging to a large 
This is an author-produced, peer-reviewed version of this article. The final, definitive version of this document can be found online at Journal of Political Science Education, published by Routledge. Copyright restrictions may apply. doi: 10.1080/15512169.2015.1071264

extent as it had components of both contemporary and classical international relations: it dealt with issues of civil war and ethnicity while also seemingly explainable by realpolitik ideas of international relations. Thus, it is possible that this presented a unique event and the five-percent bump was really caused by a stochastic, exogenous shock in the international system.

I am not persuaded by this. Ultimately, any semester in which we offer international relations will have events that drive scholarly and non-scholarly work. As I prepared for the fall semester in 2014, the Islamic State of Iraq and Syria has made significant in-roads in taking over portions of Iraq and questions about US intervention, the right to protect, counter-revolutionary and ethnic factions, and stability in the Middle East are present topics across political science blogs. In fall 2013, the control group in this study, attention-grabbing current events that would demand student attention included the use of chemical weapons in Syria and potential US action against the country, Egypt's state of emergency, the fallout from NSA spying on US allies, progress in Iranian nuclear talks, and deteriorating peace talks between Israel and Palestine. Each of these topics spawned blogs posts and underscore pivotal concepts in international relations while exposing students to contemporary dilemmas in international affairs.

Second, the sample size of the study presents intriguing initial findings, but the two-class model over two semesters leave avenues for exploration. The models above offer 60-64 observations and the OLS models provide unbiased estimates, but suffer from larger standard errors from the limited sample space. Additionally, the research design presents a challenge to inference in regards to the gains of the spring versus fall students: notably, it is possible that spring students have higher academic achievement than fall students. The literature on spring versus fall student dynamics is thin, but there are a couple of reasons why this may be the case. First, the gap between Spring-Fall and Fall-Spring is much larger with the summer break in the average college and student retention may be lower (DeVito and Long 1977). Second, first-year students who do well in their first semester of college are more likely to continue while those who do poorly may drop out of the program or college leading to a biased spring sample (Murtaugh, Burns, and Schuster 1999). Third, it is possible that I became more proficient at teaching the course from one semester to the next and boosted my students' achievement.

For this study, my students were all upper-division students with no first-year students. As a result, the potential biased sample problem becomes less likely as students are more adjusted to their college life by their third and fourth year of college. Additionally, some research suggests that spring seniors may be worse performers than earlier students due to the extrinsic motivation problems inherent to the final semester of courses. Given the sample of students studied here, this may be an issue. Regardless, there is enough evidence to suggest that future work may want to examine early-career students as departments generally offer their introductory courses to first- and secondyear students; scholars pursuing this research further should certainly devise ways to account for the threat of semesterbased performance in future research, perhaps by offering the blog readings in the fall and leave their control comparison for the spring. Flipping the order of semesters in the research (or doing the study on two different classes in the same semester if teaching demands allow for it) would also allow for a check on the proficiency issue. This was my sixth and seventh time teaching this particular course and I did not vary the content in between the classes, but it is another concern that solid research design can eliminate in the future.

The extant literature on topics related to this research generally deals with writing blogs and reading newspapers in the classroom; however, I do not compare blog consumption to newspaper consumption. It is possible that how students interpret and internalize information varies based on the medium they interact with. Another potential avenue for future research could be to compare newspapers (or online news sources) in the classroom relative to blogs written by political scientists. Such a study would both gives us more insight into the classroom as well as inform the discipline if we are better at conveying current events to our undergraduates than journalists.

There is a vast amount of blog material already available online and this presents another avenue for future research: A follow-up study could use known blog articles to directly complement existing course material to see if the results come from having additional and alternative avenues to access information, or if the real-time nature of current events is primarily responsible for the increase in student performance. This approach creates a controlled set of articles for students to consume and may reduce the variance of international politics as it relates to the mastery of international relations concepts. 
This is an author-produced, peer-reviewed version of this article. The final, definitive version of this document can be found online at Journal of Political Science Education, published by Routledge. Copyright restrictions may apply. doi: 10.1080/15512169.2015.1071264

In one approach for future research, the researcher assigns blog articles every week to determine whether a guided review of blogs increases student comprehension and if it affects their propensity to read political science posts in the future. Another option is to have students post their own analyses by applying class concepts to current events. The research seems to generally indicate that getting students to write with some level of peer discussion has positive effects on comprehension and performance. Thus, a blog that is internal to the classroom may prove to be an effective third avenue. ${ }^{12}$

Returning to the topic that I opened the article with, curtailing blogging by political scientists of any level or affiliation makes our access to political science research poorer. Having standards for what constitutes an acceptable, professional blogging persona is reasonable, but an embargo on online publication may not only hurt scholars underneath the embargo, but also students within our classrooms.

\section{References}

Arena, Phil. 2014. “Sanction Threats, Imposition, and Protest.” Duck of Minerva. 18 April. Date Accessed: 2/17/2015. http://duckofminerva.com/2014/04/sanction-threats-imposition-and-protest.html

Arthur, Neal and Patricia Everaert. 2012. "Gender and Performance in Accounting Examinations: Exploring the Impact of Examination Format.” Accounting Education 21(5):471-487.

Bacon, Donald R. 2003. "Assessing learning outcomes: A Comparison of Multiple-Choice and Short-Answer Questions in a Marketing Context.” Journal of Marketing Education 25(1):31-36.

Bates, Robert H. 2001. Prosperity and Violence: The Political Economy of Development. New York City, NY: W.W. Norton.

Benstead, Lindsay, Alexander Kjaerum, Ellen Lust \& Jakob Wichmann. 2014. “Libya's Security Dilemma.” The Monkey Cage. 1 April. Date Accessed: 2/17/2015. http://www.washingtonpost.com/blogs/monkeycage/wp/2014/04/07/libyas-security-dilemma/

Bridgeman, Brent \& Charles Lewis. 1994. "The Relationship of Essay and Multiple-Choice Scores with Grades in College Courses.” Journal of Educational Measurement 31(1):37-50.

Carpenter, Charli. 2014. "Report: US Drone Casualty Estimates Are Likely Too Low.” Duck of Minerva. 10 April. Date Accessed: 2/17/2015.http://duckofminerva.com/2014/04/report-us-drone-casualty-estimates-arelikely-too-low.html

DeRoche, Edward F. 1981. “Newspapers in Education: What We Know.” Newspaper Research Journal 2(3):59-63.

DeVito, Pasquael I. and John V. Long. 1977. "The Effects of Spring-Spring vs. Fall-Spring Testing Upon the Evaluation of Compensatory Education Programs.” Paper presented at Annual Meeting of the American Educational Research Association. AERA.

Divitini, Monica, Ove Haugalokken \& Eli M Morken. 2005. Blog to Support Learning in the Field: Lessons Learned from a Fiasco. In Proceedings of the Fifth IEEE International on Advanced Learning Technologies. IEEE Computer Society pp. 219-221.

Drezner, Daniel W. 2003. “The Hidden Hand of Economic Coercion.” International Organization 57(03):643-659.

Drezner, Daniel W. 2011. Theories of International Politics and Zombies. Princeton, NJ: Princeton University Press.

Farrell, Henry. 2014a. "The Political Science of Cybersecurity I Why People Fight So Hard over Cybersecurity.” The Monkey Cage. 23 January. Date Accessed: 2/17/2015. http://www.washingtonpost.com/blogs/monkeycage/wp/2014/01/23/the-political-science-of-cybersecurity-i-why-people-fight-so-hard-over-cybersecurity/

Farrell, Henry. 2014b. "The Political Science of Cybersecurity III How International Relations Theory Shapes U.S. Cybersecurity Doctrine.” The Monkey Cage. 20 February. Date Accessed: 2/17/2015. http://www.washingtonpost.com/blogs/monkey-cage/wp/2014/02/20/the-political-science-of-cybersecurity-iiihow-international-relations-theory-shapes-u-s-cybersecurity-doct

Frieden, Jeffry A., David A. Lake \& Kenneth A. Schultz. 2012. World Politics: Interests, Interactions, Institutions. 2nd ed. New York City, NY: W.W. Norton.

Gartzke, Erik \& Yonatan Lupu. 2014. "What World War I Can Tell Us About International Commerce and War Today.” The Monkey Cage. 1 April. Date Accessed: 2/17/2015. http://www.washingtonpost.com/blogs/monkey-cage/wp/2014/04/01/ what-world-war-i-can-tell-us-aboutinternational-commerce-and-war-today/

\footnotetext{
${ }^{12}$ A public blog by students is a riskier proposition given the permanence of online work and students may be less
} comfortable opening up their budding analyses to the rest of the world. 
This is an author-produced, peer-reviewed version of this article. The final, definitive version of this document can be found online at Journal of Political Science Education, published by Routledge. Copyright restrictions may apply. doi: 10.1080/15512169.2015.1071264

Ghorpade, Jai \& James R Lackritz. 1998. "Equal Opportunity in the Classroom: Test Construction in a DiversitySensitive Environment.” Journal of Management Education 22(4):452-471.

Goldsmith, Benjamin E., Yusaku Horiuchi \& Terence Wood. 2014. "Doing Well by Doing Good: Foreign Aid Improves Opinions of The U.S.” The Monkey Cage. 14 April. Date Accessed: 2/17/2015. http://www.washingtonpost.com/blogs/monkey-cage/wp/2014/04/14/ doing-well-by-doing-good-foreign-aidimproves-opinions-of-the-u-s/

Harvey, CC \& Cecil F Denton. 1938. “Use of Newspapers in Secondary Schools.” The School Review pp. 196-201.

Hayes, Jarrod. 2014. “Crimea is Not a Realist Story.” Duck of Minerva. 10 April. Date Accessed: 2/17/2015. http://duckofminerva.com/2014/04/crimea-is-not-a-realist-story.html

Heron, Emma \& Mike McManus. 2003. "Political Literacy and the Teaching of Social Policy. A Study into the Political Awareness and Political Vocabularies of First Year Undergraduates.” Social Policy and Society 2(01):23-32.

Izama, Melina Platas \& Kim Yi Dionne. 2014. "U.S. Foreign Policy and Ugandan Domestic Politics Collide.” The Monkey Cage. 7 April. Date Accessed: 2/17/2015. http://www.washingtonpost.com/blogs/monkeycage/wp/2014/04/07/ u-s-foreign-policy-and-ugandan-domestic-politics-collide/

Jarman, Ruth \& Billy McClun. 2001. "Use the News: A Study of Secondary Teachers' Use of Newspapers in the Science Classroom.” Journal of Biological Education 35(2):69-74.

Kang, Inae, Curtis J Bonk \& Myung-Chun Kim. 2011. "A Case Study of Blog-Based Learning in Korea: Technology Becomes Pedagogy.” The Internet and Higher Education 14(4):227-235.

Kim, Hyung Nam. 2008. "The Phenomenon of Blogs and Theoretical Model of Blog Use in Educational Contexts." Computers \& Education 51(3):1342-1352.

Lacroix, Steéphane. 2014. “Saudi Arabia’s Muslim Brotherhood Predicament.” The Monkey Cage. 20 March. Date Accessed: 2/17/2015. http://www.washingtonpost.com/blogs/monkey-cage/wp/2014/03/20/saudi-arabiasmuslim-brotherhood-predicament/

Lee, Lina. 1999. "Going Beyond Classroom Learning: Acquiring Cultural Knowledge via On-Line Newspapers and Intercultural Exchanges via On-Line Chatrooms.” CALICO journal 16(2):101-120.

Lin, Wei-Jane, Yi-Ling Liu, Koh Kakusho, Hsiu-Ping Yueh, Masayuki Murakami \& Michihiko Minoh. 2006. Blog as a Tool to Develop E-Learning Experience in an International Distance Course. In Advanced Learning Technologies, 2006. Sixth International Conference on. IEEE pp. 290-292.

Marten, Kimberly. 2014. “How Might Sanctions Affect Russia?” The Monkey Cage. 4 March. Date Accessed: 2/17/2015. URL: http://www.washingtonpost.com/blogs/monkey-cage/wp/2014/03/04/ how-might-sanctionsaffect-russia/

Mueller, John. 2014. “Economic Interdependence as a Facilitator of War?” Duck of Minerva. 13 March. Date Accessed: 2/17/2015. http://duckofminerva.com/2014/03/economic-interdependence-as-a-facilitator-ofwar.html

Murdie, Amanda. 2014a. "Dear Kansas Board of Regents.” The Duck of Minerva. 19 December.

Date Accessed: 8/20/2014. http://www.whiteoliphaunt.com/duckofminerva/2013/12/dear-kansas-board-ofregents.html

Murdie, Amanda. 2014b. “'Shame’ On You, ISA.” The Duck of Minerva. 29 January. Date Accessed: 8/20/2014. http://www.whiteoliphaunt.com/duckofminerva/2014/01/shame-on-you-isa.html

Murtaugh, Paul A., Leslie D. Burns \& Jill Schuster. 1999. "Predicting the Retention of University Students.” Research in Higher Education 40(3):355-371.

Nagl, John A. 2009. Learning to Eat Soup with a Knife: Counterinsurgency Lessons from Malaya and Vietnam. Chicago, IL: University of Chicago Press.

Nugent, Elizabeth. 2014. “How Repressing The Brotherhood Could Have Unintended Consequences In Egypt.” The Monkey Cage. 23 January. Date Accessed: 2/17/2015.http://www.washingtonpost.com/blogs/monkeycage/wp/2014/01/23/how-repressing-the-brotherhood-could-have-unintended-consequences-in-egypt/

Onuch, Olga \& Gwendolyn Sasse. 2014. “What Does Ukraine’s \#Euromaidan Teach Us About Protest?” The Monkey Cage. 27 February. Date Accessed: 2/17/2015. URL: http://www.washingtonpost.com/blogs/monkeycage/wp/2014/02/27/ what-does-ukraines-euromaidan-teach-us-about-protest/

PewResearch. 2013. “Amid Criticism, Support for Media's 'Watchdog' Role Stands Out.” Center for the People \& the Press. 8 August. Date Accessed: 8/20/2014. http://www.people-press.org/2013/08/08/amid-criticism-supportfor-medias-watchdog-role-stands-out/

Radnitz, Scott. 2014. "How to Prevent the Crisis in Ukraine from Escalating.” The Monkey Cage. 28 February. Date Accessed: 2/17/2015. http://www.washingtonpost.com/blogs/monkey-cage/wp/2014/02/28/ how-to-preventthe-crisis-in-ukraine-from-escalating/ 
This is an author-produced, peer-reviewed version of this article. The final, definitive version of this document can be found online at Journal of Political Science Education, published by Routledge. Copyright restrictions may apply. doi: 10.1080/15512169.2015.1071264

Rodriguez, Michael C. 2003. "Construct Equivalence of Multiple-Choice and Constructed-Response Items: A Random Effects Synthesis of Correlations.” Journal of Educational Measurement 40(2):163-184.

Saideman, Stephen M. 2014. “Are Blogs Inherently Unprofessional.” Saideman’s Semi-Spew. 27 January. Date Accessed: 8/20/2014. http://saideman.blogspot.ca/2014/01/are-blogs-inherently-unprofessional.html

Shibley Jr, Ivan A. 2003. "Using Newspapers to Examine the Nature of Science.” Science \& Education 12(7):691702.

Sim, Jeffrey Wee Sing \& Khe Foon Hew. 2010. "The Use of Weblogs in Higher Education Settings: A Review of Empirical Research.” Educational Research Review 5(2):151-163.

Stacey, Jeffrey. 2014. "France’s Re-Emergence as a Major Power.” Duck of Minerva. 19 January.

Date Accessed: 2/17/2015. http://duckofminerva.com/2014/01/frances-re-emergence-as-a-major-power.html

Steele, Abbey. 2014. “Electing Peace in Colombia?” The Monkey Cage. 20 March. Date Accessed: 2/17/2015. http://www.washingtonpost.com/blogs/monkey-cage/wp/2014/03/20/ electing-peace-in-colombia/

Straumsheim, Carl. 2014. “Is Blogging Unscholarly?” Inside Higher Ed. 29 January. Date Accessed: 8/20/2014. https://www.insidehighered.com/news/2014/01/29/ international-studies-association-proposes-bar-editorsbloggingdThomas, Jakana. 2014a. “Actually, sometimes terrorism does work.” The Monkey Cage. 22 April. Date Accessed: 2/17/2015. URL: http://www.washingtonpost.com/blogs/monkey-cage/wp/2014/04/22/ actually-sometimes-terrorism-does-work/

Thomas, Jakana. 2014b. “Five Lessons For China About ‘Peaceful Rise’ From 1914.” The Monkey Cage. 28 April. Date Accessed: 2/17/2015. http://www.washingtonpost.com/blogs/monkey-cage/wp/2014/04/28/ five-lessonsfor-china-about-peaceful-rise-from-1914/

Traub, Ross E \& Charles W Fisher. 1977. "On the Equivalence of Constructed-Response and Multiple-Choice Tests.” Applied Psychological Measurement 1(3):355-369.

Travlos, Konstantinos. 2014. "Why the Crimea is the Third Rail of International Politics." Duck of Minerva. 1 March. Date Accessed: 2/17/2015. http://duckofminerva.com/2014/03/ why-the-crimean-is-the-third-rail-ofinternational-politics.html

Voeten, Erik. 2014a. "How Religious Minorities Helped Rescue Jews in the Netherlands During the Holocaust.” The Monkey Cage 27 February. Date Accessed: 2/17/2015. http://www.washingtonpost.com/blogs/monkeycage/wp/2014/03/18/ how-religious-minorities-helped-rescue-jews-in-the-netherlands-during-theholocaust//

Voeten, Erik. 2014b. "International Law and Institutions Look Pretty Weak Now, But They Will Matter A Lot Down The Road.” The Monkey Cage. 27 February. Date Accessed: 2/17/2015. http://www.washingtonpost.com/blogs/monkey-cage/wp/2014/03/02/ international-law-and-institutions-lookpretty-weak-now-but-they-will-matter-a-lot-down-the-road/

Ward, Steven \& Paul Musgrave. 2014. “Cutting Arms and Tying Hands?” Duck of Minerva. 25 February. Date Accessed: 2/17/2015. http://duckofminerva.com/2014/02/cutting-arms-and-tying-hands.html

Wolczuk, Kataryna \& Roman Wolczuk. 2014. "How Protest and Violence in Ukraine Could Give Way to Unity.” The Monkey Cage. 28 January. Date Accessed: 2/17/2015. http://www.washingtonpost.com/blogs/monkeycage/wp/2014/01/28/ how-protest-and-violence-in-ukraine-could-give-way-to-unity/ 